\title{
FLOTATION STUDIES OF COPPER ORE MAJDANPEK TO ENHANCE COPPER RECOVERY AND CONCENTRATE GRADE WITH DIFFERENT COLLECTORS
}

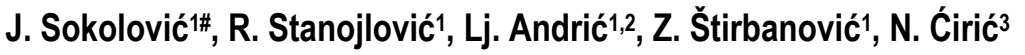 \\ 1 University of Belgrade, Technical Faculty in Bor, Bor, Serbia \\ 2Institute for Technology of Nuclear and other Mineral Raw Materials (ITNMS), Belgrade, Serbia \\ 3Zijin Bor Copper d.o.o, Copper Mine Majdanpek - RBM, Majdanpek, Serbia
}

(Received: October 25, 2019; Accepted: November 25, 2019)

\begin{abstract}
This paper presents the results of mineralogical and flotation studies on the copper ore from the deposit "North Revir" in the Copper Mine Majdanpek, using different collectors. XRD and ore mineralogical analysis showed that the most common minerals are pyrite and chalcopyrite. Chemical analysis confirm that it is a complex low-grade copper ore with average copper content of $0,273 \%$. The content of precious metals ( $A u$ and $\mathrm{Ag}$ ) was $0.2 \mathrm{~g} / \mathrm{t}$ and $1.2 \mathrm{~g} / \mathrm{t}$, respectively. The main aim of flotation studies have been the effect of collector type on the recovery and concentrate grade in the copper flotation process. Various collectors and combinations of them were used in the rough flotation tests of copper ore. The copper recovery was in the range from $79.43 \%$ (test no. 4) to $84.96 \%$ (test no. 7). The best flotation results were obtained with mixture collectors of sodium isopropyl xanthate (Z11), dialkyl dithiophosphinates (Aerophine 3404) and SKIK BZ 2000. The collector's dosages of $20 \mathrm{~g} / \mathrm{t} \mathrm{Z11,} 8 \mathrm{~g} / \mathrm{t}$ AP3404 and 8 g/t SKIK BZ 2000 produced the copper recovery (84.96 \%) with copper concentrate grade of $1.52 \%$
\end{abstract}

Key words: Copper; Ore; Majdanpek; Flotation; Collectors.

\section{Introduction}

Copper is one of the oldest metals ever used, and has been one of the most important and most useful metals in the development of civilization. Due to its physical and chemical properties and characteristics, copper has exceptional economic potential and strategic importance in the world as well as in the Republic of Serbia.

In 2018 global demand for copper was 23.6 million tons and it will continue to rise to $29.8 \mathrm{Mt}$ by 2027 - at $2.6 \%$ annual growth [1]. On the other hand, global copper mine production has grown by $3.2 \%$ per annum to 20.6 million tonnes in 2018. In 2018, five countries (Chile, Peru, China, USA and Congo) were producing about $60 \%$ of world copper production. Chile is a world's leading copper mine producer in 2018 with a mine output of 5.8 million tonnes of copper [1].

The world copper reserves are estimated at about 5.6 billion tons [2]. According to a recent report published by United States Geological Survey (USGS), the identified and undiscovered reserves are estimated at 2.1 and 3.5 billion tonnes of copper, respectively [2]. Also, about 1.8 billion tonnes are estimated in the porphyry copper deposits [3]. The world's largest estimated copper ore reserves are in Chile and are around $40 \%$. In the Republic of Serbia, it is estimated that the total geological copper ore reserves amount to about 2.576 billion tonnes and total copper reserves currently amount about 8.1 million tonnes [4].

Copper ore processing in Serbia has a long tradition. The most important copper ores in Serbia are located in the Bor metallogenic zone of the Carpatho-Balkanian metallogenic province such as: porphyry copper deposits Borska Reka, Veliki Krivelj and Majdanpek [5].

Copper and gold/silver, accompanied by iron (sulphide, oxide), molybdenum, sporadically PGE,

\#Corresponding author: jsokolovic@tfbor.bg.ac.rs

doi: 10.5937/JMMA1901053S 
are the predominant metals in the Bor metallogenic zone. Since 1902, the total production has been approximately $652 \mathrm{Mt}$ of ore with $4.93 \mathrm{Mt}$ of copper and 280 tons of gold [5].

The Copper Mine Majdanpek (RBM), as a part of Zijin Bor Copper d.o.o. (formerly known as RTB Bor), with a long history of copper production in Serbia, is one of the largest copper mines. Located in the eastern part of Serbia, Majdanpek deposit represents one of the most abundant copper reserves in Serbia and in the world.

Majdanpek porphyry copper deposit represents one of the largest copper reserve in Serbia. It is located in the northern part of the Timok Magmatic Complex (TMC), which is a part of a geological framework that includes the Alpine - Balkan Carpathian - Dinaride metallogenic - geodynamic province [6] also referred to as the Carpatho Balkan Magmatic Belt [7]. The TMC complex in a lozenge shaped belt, almost $100 \mathrm{~km}$ in length in the direction north-south, up to $25 \mathrm{~km}$ of width, with a total area of around $1130 \mathrm{sq} . \mathrm{km}$ [8].

The Majdanpek deposit, with an average width of $300 \mathrm{~m}$, is approximately $5 \mathrm{~km}$ in length [8]. Weak copper mineralization $(>0.1 \% \mathrm{Cu})$ was detected to a depth of at least $1 \mathrm{~km}$ [9]. This deposit consists of porphyry copper-gold deposit with associated replacement deposits (skarns, mantos) and highsulphidation epithermal massive-enargite (gold) sulphide deposits [10]. Mineralization typically occurs in a form of stockworks, within the metamorphic aureole of the andesitic dykes.

This deposit includes two major mining areas, i.e. two different copper deposits: North Revir and South Revir. Both deposits are studied and described in detail by Armstrong et al. (2005) [8]. South Revir is the largest deposit with significant mineralization and copper occurrence, the $\mathrm{Cu}-\mathrm{Au}$ rich massive Knez Lazar body and a number of contact skarns [8]. The second copper deposit "North Revir" contains three ore bodies: 1) Porphyry ore bodies: "Central ore body" and "Dolovi", 2) Cu-pyrite ore bodies: "Dolovi 2" and "Stari Dušan" and 3) Polymetallic ore body Tenka [9]. According to the Armstrong et al. (2005), it is characterized by the presence of polymetallic $\mathrm{Pb}$ -
Zn rich limestone with several smaller porphyry copper ore bodies [8].

The total copper reserves of the ore at Majdanpek were estimated at $800 \mathrm{Mt}$, containing $0.4-0.8 \% \mathrm{Cu}$, and 0.25-1.0 g/t Au [10]. The exploitation in the Copper Mine Majdanpek started in the early 1955. The plans for development of the complex included the opening of an open-pit mine, construction of a flotation plant and related facilities and development of an urban settlement.

During the 1980s, the production capacity reached about 13 million tons of ore per year [11]. Flotation plant produced copper (with gold and silver) and magnetite concentrates. In the recent years, the annual capacity decreased significantly (in 2005 it amounted to about 1.2 million tons of ore), mainly due to the lower content of copper in the ore [11]. Due to the decreased mine production, the flotation plant is reportedly running at $25 \%$ of its capacity. The Copper Mine Majdanpek increased its production of copper concentrate, gold and silver by about $40 \%$ in 2016 with $7.8 \mathrm{~g} / \mathrm{t} \mathrm{Au}, 0.03 \mathrm{~g} / \mathrm{t} \mathrm{Pt}$, and $0.27 \mathrm{~g} / \mathrm{t} \mathrm{Pd}$ in concentrate [12].

Flotation is a physicochemical process that has been used for more than a century in the concentration of copper ores. Mineralogy, particle size, degree of liberation, collector type and dosage, air flow rate, pulp density, and wash water rate are some of the influential parameters on flotation process efficiency [13-20].

A literature review showed that collectors play a critical role in the flotation of copper ores. A number of different collectors have been evaluated for copper flotation. The xanthates, dialkyl dithiophosphates and dithiocarbamates are the most widely used as collectors for copper flotation [21].

Many studies into collectors for copper flotation have been carried out [22-29].

Hangone et al. (2005), in a study of the effects of thiol collectors: xanthates, dithiophosphates, dithiocarbamates and mixtures of these collectors in the flotation of a copper sulphide ore, showed the di-ethyl-dithiocarbamate was the weakest collector of copper sulphide minerals. It was also 
found that highest copper recoveries were obtained with the di-ethyldithiophosphate as well as that a collector mixture of $90 \%$ ethyl xanthate : $10 \%$ diethyldithiophosphate and $90 \%$ ethyl xanthate : $10 \%$ di-ethyl-dithiocarbamate resulted in enhanced rates and copper recoveries [22].

Bradshaw and O'Connor (1994) showed that an optimum ratio of the constituent collectors of collector mixtures was $90: 10 \%$ mixture of xanthate and dithiocarbamate collectors in the flotation of pyrite [23]. Later, Bradshaw et al. [24] were tested the synergistic interactions between Potassium nbutyl xanthate (PNBX) and a dithiocarbamate collector (DTC) in sulphide flotation both as pure collectors and as components in a collector mixture. As results of batch flotation, froth surface and thermochemical tests, it is observed that the mixture of collectors showed a stronger adsorption than the pure xanthate, an increase in bubble loading, an improvement in froth characteristics and a greater grade and recovery.

Lee et al. (2009) studied flotation of mixed copper oxide and sulphide minerals with xanthate and hydroxamate collectors [25]. This investigation has shown that using n-octyl hydroxamates (AM28 made by Ausmelt Limited) with traditional sulphide collectors (PAX) can successfully recover copper sulphides and oxides by flotation from a high grade copper-gold deposit in Yukon, Canada.

Corin et al. [26] has investigated the roles of two collectors sodium iso-butyl xanthate (SIBX) and sodium di-ethyldithiophosphate (DTP) in the flotation of platinum group mineral (PGM) ore. Results showed that SIBX is a stronger collector and that DTP plays an important role in the recovery of fine particles and an increase in the recovery of PGEs, especially Pd, from the Platreef deposit in South Africa.

The interaction between the sulfide minerals surface and n-octanohydroxamate collector $(\mathrm{pH}>$ 9) was investigated by Parker et al. [27] through electrochemical, Raman spectroscopy and X-ray photoelectron spectroscopy analysis, and it was found that on the ternary sulfide minerals such as chalcocite, bornite and chalcopyrite, $\mathrm{Cu}$ hydroxamate was formed between patches of $\mathrm{Fe}$ oxide bearing adsorbed $\mathrm{Fe}$ hydroxamate and/or hydroxamic acid. Also, these results confirm that pyrite did not react significantly with noctanohydroxamate unless the surface was preoxidized.

The role of collectors and depressants in flotation, based on the extended DerjaguinLandau-Verwey-Overbeek (DLVO) theoretical model proposed by Suresh and Walz [28] was studied by Xing et al. (2017) [29].

Previously, copper flotation and the effect of collector type on the recovery of the flotation process have been studied on copper ore from Majdanpek deposit [30-31].

The flotation studies on ore from Majdanpek deposit have been conducted in order to determine the efficiency of flotation in dependence of a minerals liberation degree and different collectors. In this study, Grujic et al. [30] used a 3418-A, S7518, APS9090 and S-5415 collectors. The characteristics of flotation reagents, the redox potential of minerals in pulp, solubility product of minerals $(\mathrm{M}+, \mathrm{A}-)$ and reactivity of flotation reagents anions and cations were investigated too. Results showed that the solubility product of minerals $(\mathrm{M}+, \mathrm{A}-)$ and redox potential of sulfide minerals of $\mathrm{Cu}, \mathrm{Au}$ and $\mathrm{Pt}$ are changing in dependence of collectors chemical structures as well as with a mixture of collectors obtained a recovery of copper, gold and platinum minerals was $87 \%, 58 \%$ and $57 \%$, respectively.

Jovanovic et al. [31] studied the effect of different collectors on the quality of copper concentrate from the deposit ore body Tenka-3 North Mining District, Copper Mine Majdanpek. The following reagents were used as collectors as well as their combinations: sodium isopropyl xanthate (NalPX), ditiophosphinate $(3418$ A) and ethoxycarbonyl thiourea (AP 5500). It was found that the best results were obtained using the collector AP 5500 at higher $\mathrm{pH}$ values range (10.0 $-11.5)$.

This paper discusses the effect of collector type and dosage on copper recovery and concentrate grade. In the study, dithiophosphate and a mixture of xanthate and dithiophosphate collectors were 
investigated with mineralogical characterization of copper ore.

\section{Experimental}

\subsection{Materials}

A representative sample of copper ore (about $160 \mathrm{~kg}$ ) was collected from the flotation plant in the Copper Mine Majdanpek (Serbia) during 2014. The sample was dried and crushed in a laboratory jaw crusher within the closed cycle with $3.37 \mathrm{~mm}$ sieve for grinding and flotation tests. Also, a representative sample of hydrocyclone overlow was taken for XRD and ore mineralogical analysis. Both samples represent a part of the copper ore that has been exploited and processed from the deposit "North Revir" with the same physicochemical characteristics and there was no difference in the composition.

\subsection{Particle size analysis}

Particle size analysis was determined by sieving of both samples on series of Tyler sieves in the range of 0.037 to $2.362 \mathrm{~mm}$. Particle size analysis of the both samples are given in Table 1 and Table 2.

Particle size analysis have shown that the main size fraction are $(+2.362) \mathrm{mm},(-2.362+1.651) \mathrm{mm}$, $(-1.651+0.417) \mathrm{mm}$ and $(-0.037+0) \mathrm{mm}$. These results confirm that the participation of coarse size is more dominant. The highest content is in the grain size fraction from 0.417 to $1.651 \mathrm{~mm}$ which amounts to $29.6 \%$. The most particles are distributed in grain size fraction $0-37 \mu \mathrm{m}$ in the hydrocyclone overlow.
As it can be seen from table 2, the content of $<37 \mu \mathrm{m}$ was determined as $43.20 \%$.

Table 1. Particle size analysis of copper ore sample

\begin{tabular}{|c|c|c|}
\hline Grain size (mm) & Mass M (\%) & $\begin{array}{c}\text { Cumulative } \\
\text { mass D (\%) }\end{array}$ \\
\hline+2.362 & 21.2 & 100.0 \\
\hline$-2.362+1.651$ & 10.8 & 78.8 \\
\hline$-1.651+0.417$ & 29.6 & 68.0 \\
\hline$-0.417+0.295$ & 4.6 & 38.4 \\
\hline$-0.295+0.208$ & 4.0 & 33.8 \\
\hline$-0.208+0.147$ & 0.8 & 29.8 \\
\hline$-0.147+0.104$ & 5.8 & 29.0 \\
\hline$-0.104+0.074$ & 2.0 & 23.2 \\
\hline$-0.074+0.053$ & 2.4 & 21.2 \\
\hline$-0.053+0.037$ & 0.6 & 18.8 \\
\hline$-0.037+0$ & 18.2 & 18.2 \\
\hline$\Sigma$ & 100.0 & \\
\hline
\end{tabular}

Table 2. Particle size analysis of hydrocyclone overlow

\begin{tabular}{|c|c|c|}
\hline Grain size (mm) & Mass M (\%) & $\begin{array}{c}\text { Cumulative } \\
\text { mass D (\%) }\end{array}$ \\
\hline+0.147 & 14.55 & 100.00 \\
\hline$-0.147+0.074$ & 26.50 & 85.45 \\
\hline$-0.074+0.037$ & 15.75 & 58.95 \\
\hline$-0.037+0$ & 43.20 & 43.20 \\
\hline$\Sigma$ & 100.00 & \\
\hline
\end{tabular}

\subsection{Chemical analyses}

The average chemical composition of copper ore sample is presented in table 3 [32].

Chemical analyses showed that average copper content was $0.273 \%$ with a dominant partition of sulfide copper $(0.253 \%)$. The content of precious metals ( $\mathrm{Au}$ and $\mathrm{Ag}$ ) was $0.2 \mathrm{~g} / \mathrm{t}$ and 1.2 $\mathrm{g} / \mathrm{t}$, respectively.

Table 3. Chemical analyses of copper ore sample

\begin{tabular}{|c|c|c|c|c|c|c|c|c|}
\hline Elements & $\begin{array}{c}\text { Cutot } \\
(\%)\end{array}$ & $\begin{array}{c}\text { Cusul } \\
(\%)\end{array}$ & $\begin{array}{c}\text { Cuox } \\
(\%)\end{array}$ & $\begin{array}{c}\mathrm{S} \\
(\%)\end{array}$ & $\begin{array}{c}\mathrm{Pb} \\
(\%)\end{array}$ & $\begin{array}{c}\mathrm{Zn} \\
(\%)\end{array}$ & $\begin{array}{c}\mathrm{Ag} \\
(\mathrm{g} / \mathrm{t})\end{array}$ & $\begin{array}{c}\mathrm{Au} \\
(\mathrm{g} / \mathrm{t})\end{array}$ \\
\hline Content & 0.273 & 0.253 & 0.02 & 4.63 & $\varnothing$ & 0.08 & 1.20 & 0.20 \\
\hline
\end{tabular}

\subsection{X-ray diffraction (XRD) analysis}

X-ray diffraction (XRD) analysis was performed on the hydrocyclone overlow sample by GNR Expoler diffractometer, with scintillation counter as detector, geometry of goniometer $\theta-\theta$, without a 
secondary monochromator. X-ray source radiation is a copper anode tube which emits characteristic CuKa radiation of wavelength $1.54 \mathrm{~A}$. Recording was done on x-ray $40 \mathrm{kV}$ tubes and $30 \mathrm{~mA}$ with a scanning rate of $3^{\circ} 2 \theta / \mathrm{min}$.

The qualitative and quantitative analysis of minerals was performed by comparing the recorded diffractograms with diffractograms from a standard database using Match data processing software [33]. With this software, based on the height of the resulting peaks, semi-quantitative determination is possible, i.e. the content of the individual minerals in the sample.

\subsection{Ore mineralogical analyses}

Qualitative mineralogical analysis of copper ore sample (hydrocyclone overlow) was carried out by ore microscopy. It was performed in reflected light in air and immersion (cedar oil), on Carl ZeissJena, JENAPOL-U microscope and system for microphotography "STUDIO PCTV" (Pinnacle) with identification of ore and non-ore minerals. Objective magnification was from 10 to $50 \mathrm{x}$ (exceptionally $100 x$ in oil immersion). Ore preparations for microscopic testing were made in plexiglass, with mineral grain and surface of $2.2 \mathrm{~cm}^{2}$.

\subsection{Grinding test}

The grinding test was carried out in a cylindrical laboratory ball mill, dimension $(\mathrm{DXL})=(400 \times 125$ $\mathrm{mm}$ ) with standard ball charge. Content of solids in grinding test was a $65 \%$ (in weight). Grinding time to achieve optimal grinding products with $65 \%$ of grain size $<0,074 \mathrm{~mm}$ was $11 \mathrm{~min}$ and $25 \mathrm{~s}$ [12].

\subsection{Flotation tests}

After grinding, copper ore samples with $65 \%$ of grain size fraction $-74 \mu \mathrm{m}$ were submitted to flotation. Flotation tests were carried out using a $2.7 \cdot 10^{-3} \mathrm{~m}^{3}$ DENVER DR-12 laboratory flotation cell with a $1250 \mathrm{rpm}$ agitation rate. Rough flotation tests were carried out with $27 \%$ solids (in weight) at $\mathrm{pH}$ 11. Furthermore, the conditioning time was 6 min, and flotation time was 17 min [12]. Sodium isopropyl xanthate (Z11), dialkyl dithiophosphinates (Aerophine 3404) and SKIK were used as collectors.

Z11 (sodium isopropyl xanthate) was provided by Chemical Industry Župa Kruševac (Serbia).

Aerophine 3404 promoter (dialkyl dithiophosphinates) is a Cytec collector. It is an effective primary collector in the selective flotation of lead/gold/silver minerals with low copper content. Aerophine 3404 promoter is highly selective against iron.

SKIK, a new domestic collector with corrosion inhibition properties, was supplied by Metoha Technology Novi Sad (Serbia).

AEROFROTH 76A (5 g/t) was used as a frother in all experiments.

The flotation tests were carried out with different collectors (alone or combination) and with different collectors dosage. Type and dosage of collectors $(\mathrm{g} / \mathrm{t})$ in the flotation tests are given in table 4 [32].

Table 4. Type and dosage of collectors $(\mathrm{g} / \mathrm{t})$ in the flotation tests

\begin{tabular}{|c|c|c|c|c|c|c|c|c|c|c|}
\hline Collector & No 1. & No 2. & No 3. & No 4. & No 5. & No 6. & No 7. & No 8. & No 9. & No 10. \\
\hline $\mathbf{Z}_{11}$ & 25 & 35 & 45 & - & - & - & 20 & 18 & 18 & 20 \\
\hline AP $_{3404}$ & - & - & - & 25 & 35 & 45 & 8 & 10 & 12 & 16 \\
\hline SKIK & - & - & - & - & - & - & 8 & 8 & 6 & - \\
\hline $\mathrm{A}_{76}$ & 5 & 5 & 5 & 5 & 5 & 5 & 5 & 5 & 5 & 5 \\
\hline
\end{tabular}

The final flotation products were filtered, dried and analysed on copper (Cu) and Sulphur (S) content, and copper and sulphur recoveries (R) were calculated using Eq. (1) [16]:

$$
R=\frac{C c}{F f} \times 100, \%
$$

The separation efficiency (SE) was calculated 
according to Eq. (2) [16]:

$S E=\frac{C m(c-f)}{F f(m-f)} \times 100, \%$

where $\mathrm{C}$ is the dried concentrate weight, $\mathrm{C}$ is the grade of $\mathrm{Cu}$ or $\mathrm{S}$ in the concentrate), $\mathrm{F}$ is the dried feed weight, $f$ is the grade of $\mathrm{Cu}$ or $\mathrm{S}$ in the feed and $\mathrm{m}$ is the maximum $\mathrm{Cu}$ or $\mathrm{S}$ content in the chalcopyrite mineral. Copper and sulphur content were determined by applying Atomic Absorption Spectrophotometry (AAS) and by gas volumetry
(GV), respectively [34].

\section{Results and discussion}

\subsection{Results of XRD analysis}

The results of the XRD analysis is shown in the diffractogram in Figure 1, and the estimated semiquantitative XRD analysis is given in Table 5 .

Results of semi-quantitative XRD analysis are shown in table 5 [32].

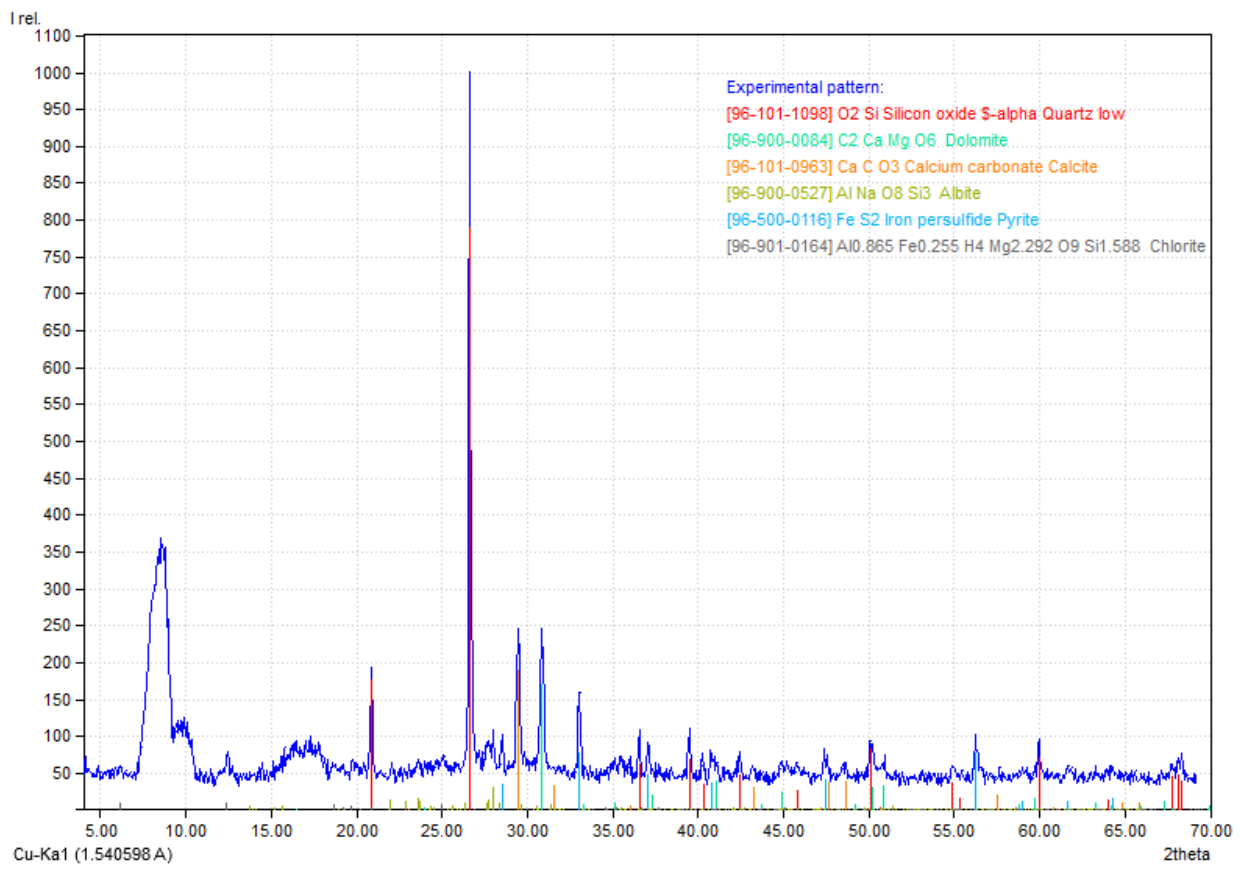

Figure 1. XRD pattern of the copper ore sample (hydrocyclone overflow)

Table 5. Results of semi-quantitative XRD analysis the copper ore sample (hydrocyclone overflow)

\begin{tabular}{|l|l|c|}
\hline Mineral & Chemical formula & Content (\%) \\
\hline Quartz & $\mathrm{SiO}_{2}$ & 49.10 \\
\hline Dolomite & $\mathrm{CaMgC}_{2} \mathrm{O}_{6}$ & 15.50 \\
\hline Calcite & $\mathrm{CaCO}_{3}$ & 13.60 \\
\hline Albite & $\mathrm{NaAlS}_{3} \mathrm{O}_{8}$ & 11.50 \\
\hline Pyrite & $\mathrm{FeS}_{2}$ & 7.30 \\
\hline Chlorite & $\mathrm{Al}_{0,865} \mathrm{Fe}_{0,255} \mathrm{H}_{4} \mathrm{Mg}_{2,292} \mathrm{O}_{9} \mathrm{Si}_{1,588}$ & 3.10 \\
\hline Chalcopyrite & $\mathrm{CuFeS}_{2}$ & 0.80 \\
\hline Chalcocite, magnetite, sphalerite & $\mathrm{Cu}_{2} \mathrm{~S} ; \mathrm{Fe}_{3} \mathrm{O}_{4} ; \mathrm{ZnS}$ & 0.20 \\
\hline
\end{tabular}


The semi-quantitative XRD analysis indicated the presence of following minerals: pyrite, chalcopyrite, chalcocite, bornite, covellite, cuprite, magnetite, rutile, limonite, sphalerite, galena, tailings minerals.

\subsection{Results of ore mineralogical analysis}

Results of ore mineralogical analysis have shown that the main copper mineral is chalcopyrite, which is compared to the ore minerals, represented by about $10 \%$, while other ore minerals (chalcocite, magnetite, sphalerite) account for about $2 \%$ (figure 2). Chalcopyrite is free about $65 \%$ (figure 2) and about $35 \%$ of chalcopyrite is usually in the form of simple and complex intergrowths, inclusions in the silicate tailings (figure 3 ), but also in the form of appropriations (inclusion) in the sphalerite.

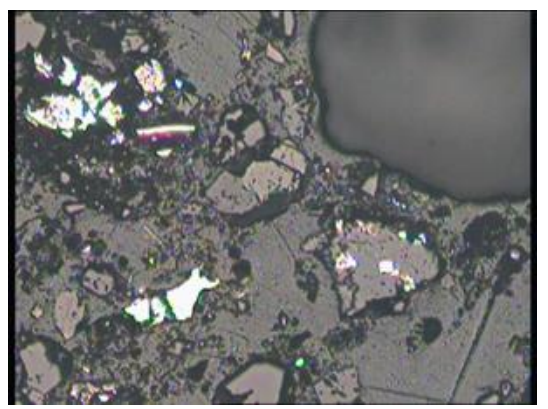

Figure 2. Free grains of chalcopyrite (yellow) and pyrite (light yellow) and inclusion of chalcopyrite in tailings

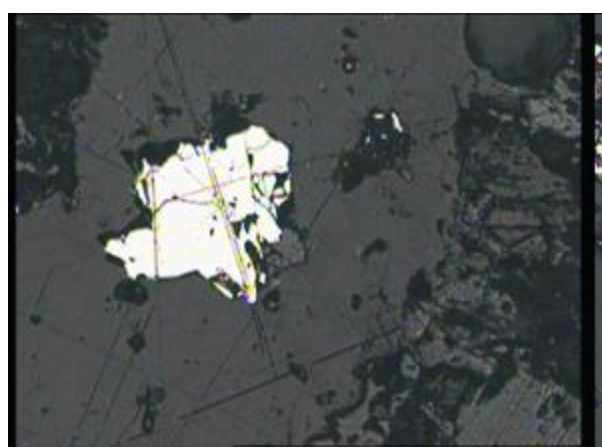

a)

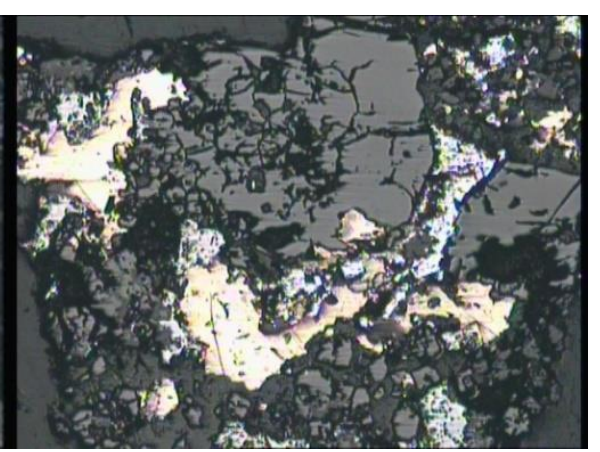

b)

Figure 3. a) Simple and b) complex intergrowts of chalcopyrite in silicate tailings

Pyrite is most abundant mineral in relation to free about $78 \%$ and about $22 \%$ of pyrite was other ore minerals. Its representation in relation to intergrown in the form of simple or complex twins the mineral ore is about $88 \%$ (its absolute (Figure 4). representation in the sample is about $9 \%$ ). Pyrite is

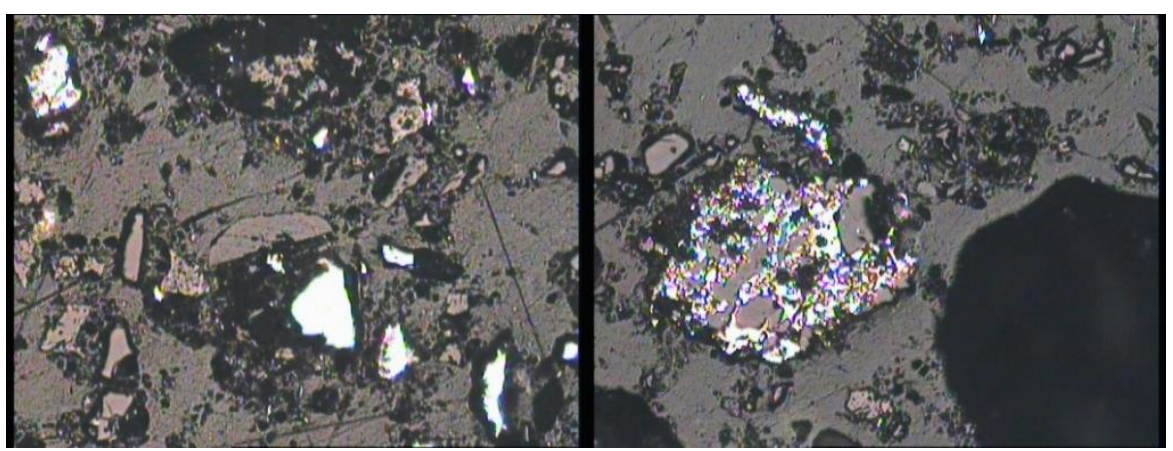

a)

b)

Figure 4. a) Liberated grains of pyrite (light yellow) and b) simple intergrowts of pyrite in silicate tailings 
The nonmetallic minerals (tailings) are feldspar (K-feldspar and plagioclase), quartz, carbonate, calcite, albite and chlorites, and the accessory tourmaline, apatite and zircon.

\subsection{Results of flotation tests}

Results of rough flotation tests of copper ore are shown in table 6 [32].

Table 6. Results of rough flotation tests of copper ore

\begin{tabular}{|c|c|c|c|c|c|c|c|}
\hline \multirow{2}{*}{$\begin{array}{c}\text { Test } \\
\text { No. }\end{array}$} & Mass yield & \multicolumn{2}{c|}{ Concentrate grade } & \multicolumn{2}{c|}{ Recovery } & \multicolumn{2}{c|}{ Separation efficiency } \\
\cline { 3 - 7 } & $(\mathbf{\%})$ & $\mathbf{C u}(\%)$ & $\mathbf{S ~ ( \% )}$ & $\mathbf{C u}(\%)$ & $\mathbf{S ~ ( \% )}$ & $\mathbf{C u}(\%)$ & $\mathbf{S}(\%)$ \\
\hline $\mathbf{1}$ & 16.39 & 1.39 & 19.87 & 83.45 & 70.34 & 67.50 & 69.08 \\
\hline $\mathbf{2}$ & 14.63 & 1.55 & 21.58 & 83.06 & 68.19 & 68.88 & 68.58 \\
\hline $\mathbf{3}$ & 15.61 & 1.42 & 22.72 & 81.19 & 76.60 & 66.01 & 78.10 \\
\hline $\mathbf{4}$ & 14.08 & 1.54 & 15.99 & 79.43 & 48.63 & 65.77 & 44.24 \\
\hline $\mathbf{5}$ & 14.44 & 1.58 & 17.92 & 83.57 & 55.89 & 69.58 & 53.07 \\
\hline $\mathbf{6}$ & 17.31 & 1.32 & 20.32 & 83.70 & 75.97 & 66.82 & 75.11 \\
\hline $\mathbf{7}$ & 15.26 & 1.52 & 24.81 & 84.96 & 81.77 & 70.16 & 85.17 \\
\hline $\mathbf{8}$ & 14.88 & 1.50 & 21.92 & 81.76 & 70.45 & 67.32 & 71.15 \\
\hline $\mathbf{9}$ & 14.09 & 1.57 & 23.43 & 81.03 & 71.30 & 67.38 & 73.26 \\
\hline $\mathbf{1 0}$ & 14.82 & 1.55 & 22.83 & 84.14 & 73.08 & 69.78 & 74.59 \\
\hline
\end{tabular}

The effects of different collectors on the separation efficiency are given on figure 5, 6 and 7 , recovery, concentrate grade as well as the respectively.

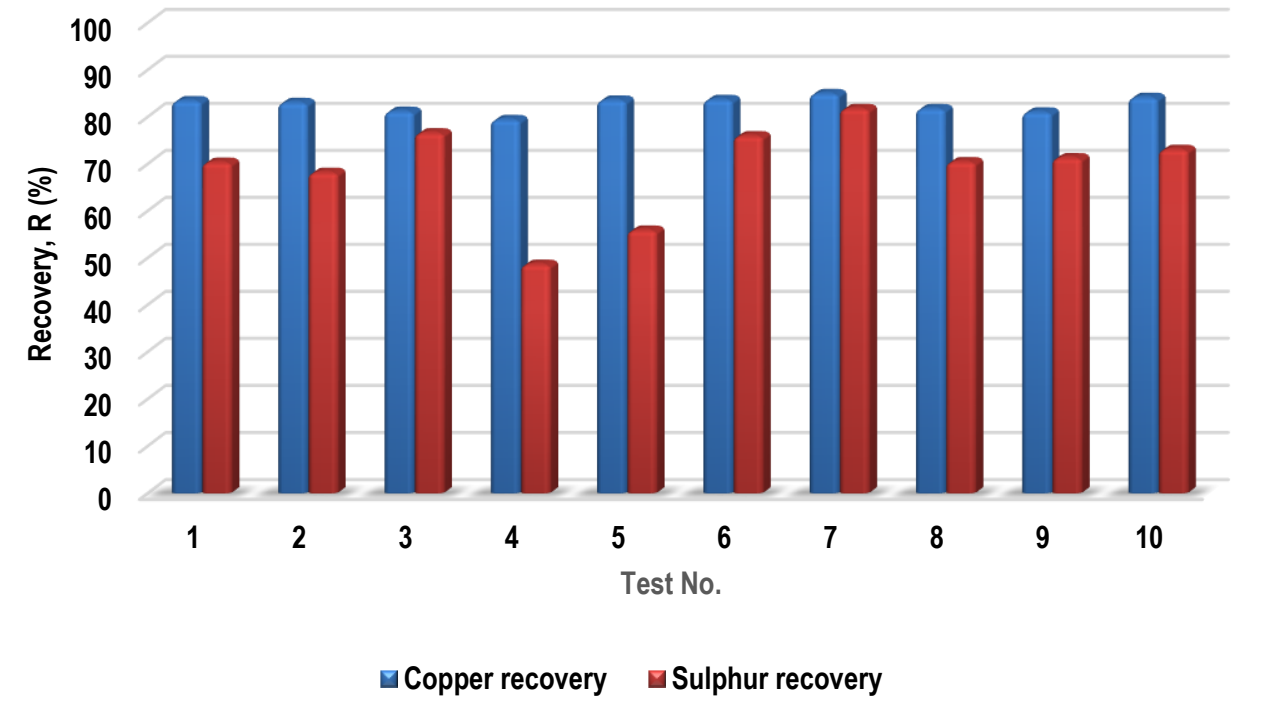

Figure 5. Effect of different collectors on the recovery

Comparing the results of the flotation tests, it can be seen that the results (the recovery, the concentrate grade as well as the separation efficiency) of tests 5,7 and 10 are relatively better than the others.
As it can be seen from table 6 (test no. 7), the collectors dosages of $20 \mathrm{~g} / \mathrm{t} \mathrm{Z11,8} \mathrm{g} / \mathrm{t} \mathrm{AP} 3404$ and $8 \mathrm{~g} / \mathrm{t} \mathrm{SKIK} \mathrm{BZ} 2000$ gave the maximum copper recovery $(84.96 \%)$. Also, rough copper concentrate grade was $1.52 \%$. 
From Fig. 7 can be seen that with these mixture of collectors a maximum values of the separation efficiency of copper $(70.16 \%)$ and sulphur $(85.17 \%)$ can be also obtained.

It can be noticed that in the flotation tests no. 5 and 10 , obtained copper recoveries were $83.57 \%$ and $84.14 \%$. The separation efficiencies were
$69.58 \%$ and $69.78 \%$, respectively. Dialkyl dithiophosphinate was used alone in the test no. 5 and the combination of collectors Z11 (sodium isopropyl xanthate) and Aerophine 3404 promoter (dialkyl dithiophosphinates) were used in test no.10. Slightly better results were achieved in the flotation test no. 10 .

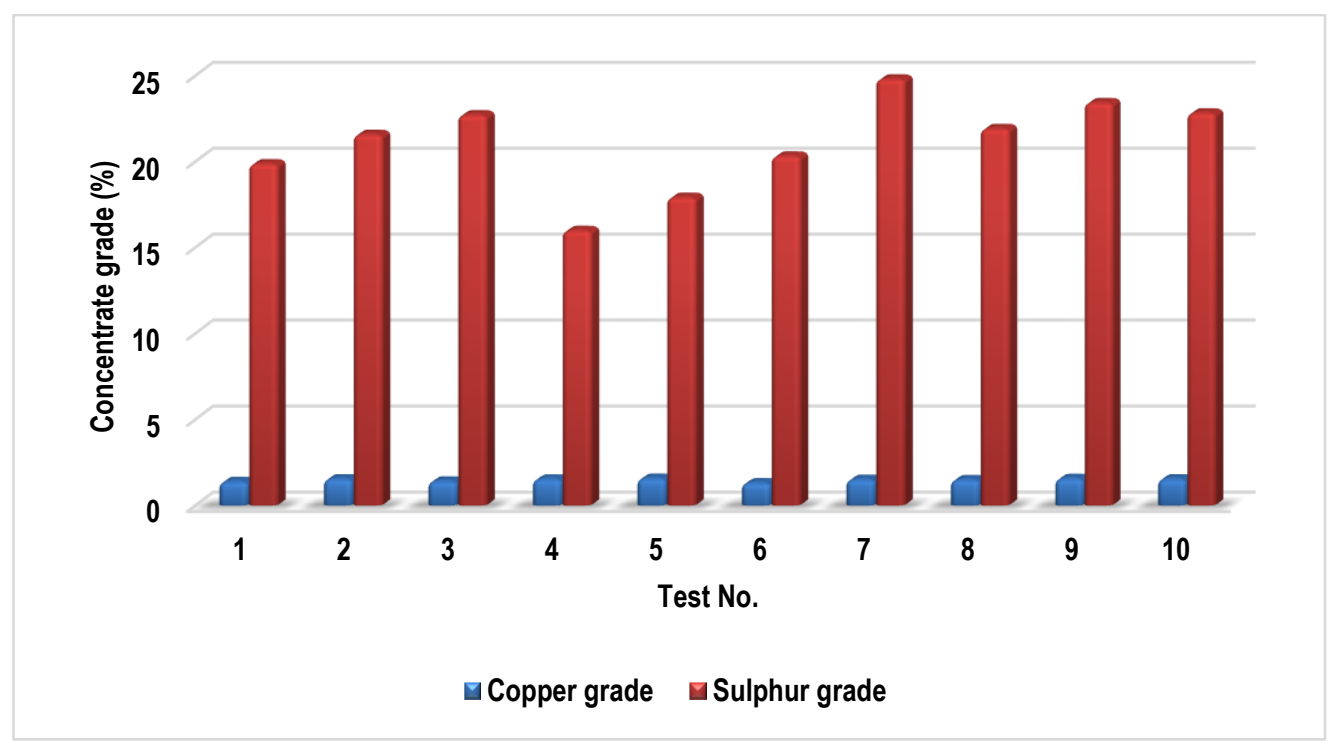

Figure 6. Effect of different collectors on the concentrate grade

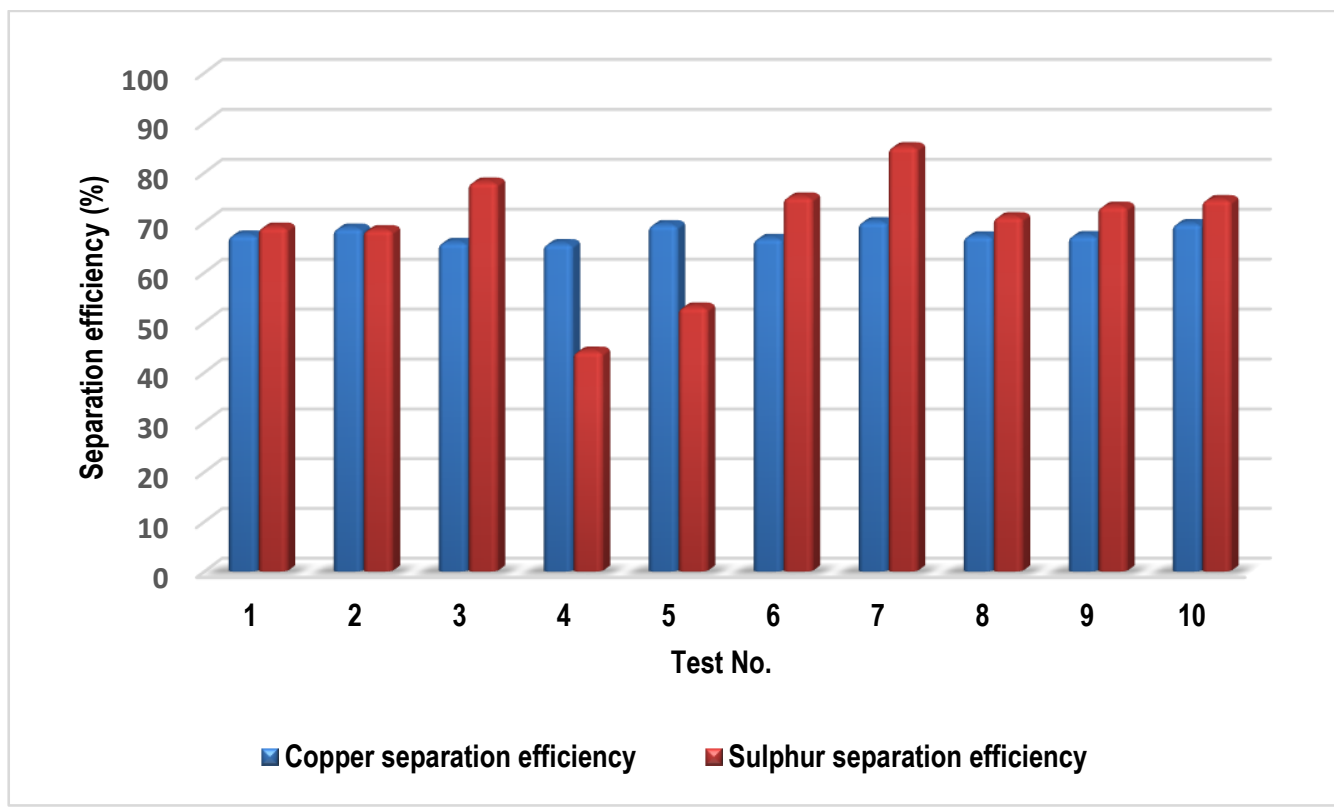

Figure 7. Effect of different collectors on the separation efficiency 
The results showed that with Z11 (sodium isopropyl xanthate) alone (test no. 1), even in smaller dosage, very good flotation results are achieved, while the use of Aerophine AP3404 in the flotation of copper ore (tests no. 5 and 6) requires a significantly higher dosage to achieve more efficient flotation.

It can be noticed that in the flotation tests in which $25 \mathrm{~g} / \mathrm{t}$ of both collectors were used, the following, noticeably different results of copper recovery were obtained: Z11 (test no. 1) - 83.45\%; and AP3404 (test no. 4) - $79.43 \%$. It was found that copper recovery increased from $79.43 \%$ to $83.70 \%$ with increasing dosage of AP3404 collector from 25 to $45 \mathrm{~g} / \mathrm{t}$. These results were achieved with a collector distribution pattern of $100 \%$.

Slightly better results were achieved with combination of both collectors such as: $20 \mathrm{~g} / \mathrm{t}$ Z11 and $16 \mathrm{~g} / \mathrm{t} \mathrm{AP3404}$ (test no. 10). Achieved copper recovery was $84.14 \%$ with $1.55 \%$ copper concentrate grade. Result of this study also show that the average copper grade in the rough concentrate was from $1.39 \%$ (test no. 1) to $1.58 \%$ (test no. 5).

By comparing obtained laboratory result with industrial result $[12,35]$ it can be seen that the better flotation result was achieved in the laboratory rough flotation test than in the industrial flotation plant of the Copper Mine Majdanpek. The mass yield, copper recovery and concentrate copper grade were $20.43 \%, 78.58 \%$ and $1.2 \%$, respectively $[12,35]$. The results of these studies confirm the necessity of applying new collectors, mixture of collectors and optimization of the collector dosage to enhance copper recovery in the flotation plant of Copper Mine Majdanpek.

\section{Conclusion}

Copper mine Majdanpek is one of the largest copper producers in Serbia. In order to improve the results of the industrial process of flotation concentration, mineralogical and rough flotation tests were carried out on ore from the deposit „North Revir".
$\mathrm{XRD}$ and ore microscopic analysis showed that the copper ore is mineralogically and texturally complex. The main copper mineral is chalcopyrite, which is, compared to the ore minerals, represented with about $10 \%$ (its absolute representation in the sample is about $0.8 \%$ ), while other ore minerals account for about $2 \%$ (their absolute representation in the sample to $0.2 \%$ ). Liberation of chalcopyrite is about $65 \%$. Pyrite is the most abundant mineral in relation to other ore mineral (about $88 \%$ ). Pyrite is liberated about $78 \%$ and about $22 \%$ of pyrite was intergrown in the form of simple or complex intergrowths (generally tailings).

The main focus of flotation studies has been the effect of a collector type on the copper recovery and concentrate grade of the flotation process. These results showed that the mixture of collectors sodium isopropyl xanthate (Z11), dialkyl dithiophosphinates (Aerophine 3404) and SKIK BZ 2000 $(56 \%, 22 \%, 22 \%)$ can produce the highest recovery $(84.96 \%)$. Copper grade in the rough concentrate was $1.52 \%$. The optimal dosages to achieve maximum recovery were found to be $20 \mathrm{~g} / \mathrm{t}$ Z11, $8 \mathrm{~g} / \mathrm{t} \mathrm{AP3404}$ and $8 \mathrm{~g} / \mathrm{t} \mathrm{SKIK} \mathrm{BZ} 2000$. Applying this combination of collectors would significantly increase copper recovery in the flotation plant of Copper Mine Majdanpek.

\section{Note}

A part of this study was presented at the XIII International Mineral Processing and Recycling Conference, organized by the University of Belgrade, Technical Faculty in Bor, from $8^{\text {th }}$ to $10^{\text {th }}$ May 2019, Belgrade, Serbia.

\section{Acknowledgements}

This paper presents the results of the Projects TR 33007 and TR 33038 funded by the Ministry of Education, Science and Technological development of the Republic of Serbia. The authors are grateful to the Ministry for financial support. 


\section{References}

[1] International Copper Study Group (2019) The world copper factbook 2019, Available at: http://www.icsg.org/index.php/component/jdow nloads/finish/170/2965; $\quad$ Retrieved: 04 September 2019.

[2] U.S. Geological Survey (2019) Mineral commodity summaries 2019: U.S. Geological Survey, $200 \mathrm{p}$..

[3] Johnson, K.M., Hammarstrom, J.M., Zientek, M.L., Dicken, C.L. (2014) Estimate of undiscovered copper resources of the world, 2013. USGS Fact sheet, 3004 (3).

[4] Strategy of Mineral Resources Management in the Republic of Serbia by 2030 (In Serbian), Government of the Republic of Serbia, Belgrade, 2012.

[5] Jelenković, R., Milovanović, D., Koželj, D., Banješević, M. (2016) The mineral resources of the Bor metallogenic zone: a review. Geologia Croatica, 69 (1), 143-155.

[6] Heinrich, C.A., Neubauer, F. (2002) Cu-Au-Pb$\mathrm{Zn}-\mathrm{Ag}$ metallogeny of the Alpine-BalkanCarpathian-Dinaride geodynamic province. Mineralium Deposita, 37(6), 533-540.

[7] Jankovic, S., Herrington, R.J., Kozelj, D. (1998) The Bor and Majdanpek copper-gold deposits in the context of the Bor metallogenic zone (Serbia, Yugoslavia). Porphyry and Hydrothermal Copper and Gold Deposits, 169178.

[8] Armstrong, R., Kozelj, D., Herrington, R., Porter, T.M. (2005) The Majdanpek Cu-Au Porphyry Deposit of Eastern Serbia: A Review. In Porter, T.M. (Ed), Super Porphyry Copper \& Gold Deposits - A Global Perspective, PGC Publishing, Adelaide, Vol. 2, pp. 453-466.

[9] Cocic, S., Jelenkovic, R., Zivkovic, P. (2002) Excursion guide. In Symposia Bor, Vol. 100, p. 115.

[10] Jelenkovic, R., Kostic, A., Zivotic, D., Ercegovac, M. (2008) Mineral resources of Serbia. Geol. Carpath, 59 (4), 345-361.

[11]Vujic, S., Grujic, M., Salatic, D., Radivojevic, S., Jelenkovic, R. (2005) Copper mine
Majdanpek: development, state, future [Rudnik bakra Majdanpek: razvoj, stanje, budućnost in Serbian, with and English abstract] Planeta print, Beograd, $171 \mathrm{p}$.

[12] Ciric, N. (2014) Investigating possibilities of improving technological process parameters of the basic flotation of copper ore from deposit "Severni revir" in the Copper Mine Majdanpek, Master thesis, University of Belgrade, Technical faculty in Bor, Bor, Serbia.

[13] Lynch, A. J., Watt, J. S., Finch, J. A., Harbort, G. E. (2007) History of flotation technology. Froth flotation: A century of innovation, 65-91.

[14] Wang, L.K., Shammas, N.K., Selke, W.A., Aulenbach, D.B. (Eds.). (2010) Flotation technology (p. 680). Totowa, NJ: Humana Press.

[15] Leja, J. (2012) Surface chemistry of froth flotation. Springer Science \& Business Media.

[16] Wills, B.A., Finch, J.A. (2016) Mineral Processing Technology: An Introduction to the Practical Aspects of Ore Treatment and Mineral Recovery. 8th ed.; ElsevierScience: New York, USA.

[17]Drzymala, J. (2018) Mineral Processing. Foundations of Theory and Practice of Minerallurgy, 2nd ed.; Oficyna Wydawnicza PWr: Wroclaw, Poland.

[18] Bahrami, A., Mirmohammadi, M., Ghorbani, Y., Kazemi, F., Abdollahi, M., Dahesh, A. (2019) Process mineralogy as a key factor affecting the flotation kinetics of copper sulfide minerals. International Journal of Minerals, Metallurgy, and Materials, 26 (4), 430-439.

[19] Marković, Z.S., Janković, A., Tomanec, R. (2008) Effect of particle size and liberation on flotation of a low grade porphyry copper ore. Journal of Mining and Metallurgy A: Mining, 44 (1), 24-30.

[20] Štirbanović, Z., Sokolović, J., Marković, I., Đorđievski, S. (2019) The effect of degree of liberation on copper recovery from copperpyrite ore by flotation. Separation Science and Technology, 1-14.

[21] Bulatovic, S.M. (2007) Handbook of flotation reagents: chemistry, theory and practice: 
Volume 1: flotation of sulfide ores. Elsevier.

[22] Hangone, G., Bradshaw, D., Ekmekci, Z. (2005) Flotation of a copper sulphide ore from Okiep using thiol collectors and their mixtures. Journal of the Southern African Institute of Mining and Metallurgy, 105 (3), 199-206.

[23] Bradshaw, D. and O'Connor, C.T. (1994) The flotation of pyrite using mixtures of dithiocarbamates and other thiol collectors. Minerals Engineering, vol. 7 (5/6), 681-690.

[24] Bradshaw, D.J., Harris, P.J., O'Connor, C.T. (1998) Synergistic interactions between reagents in sulphide flotation. Journal of The South African Institute of Mining and Metallurgy, 98 (4), 187-192.

[25] Lee, K., Archibald, D., McLean, J., Reuter, M. A. (2009) Flotation of mixed copper oxide and sulphide minerals with xanthate and hydroxamate collectors. Minerals engineering, 22 (4), 395-401.

[26] Corin, K.C., Bezuidenhout, J.C., O'Connor, C.T. (2012) The role of dithiophosphate as a co-collector in the flotation of a platinum group mineral ore. Minerals engineering, 36, 100104.

[27] Parker, G.K., Buckley, A.N., Woods, R., Hope, G.A. (2012) The interaction of the flotation reagent, n-octanohydroxamate, with sulfide minerals. Minerals Engineering, 36, 81-90.

[28] Suresh, L., Walz, J.Y. (1996) Effect of surface roughness on the interaction energy between a colloidal sphere and a flat plate. Journal of Colloid and Interface Science, 183 (1), 199213.

[29] Xing, Y., Gui, X., Karakas, F., Cao, Y. (2017) Role of Collectors and Depressants in Mineral
Flotation: A Theoretical Analysis Based on Extended DLVO Theory. Minerals, 7 (11), 223.

[30] Grujić, M., Salatić, D., Đurković, I., Grujić, M. M. (2004) Flotability of copper, gold and platinum minerals in function of liberation rate and applied collectors. Journal of Mining and Metallurgy A: Mining, 40 (1), 33-47.

[31] Jovanović, I., Ljubojev, M., Milošević, V., Todorović, D. (2016) The effect of different collectors on the quality of basic copper concentrate of the ore body Tenka. Mining and Metallurgy Engineering Bor, (2), 25-30.

[32] Sokolović, J., Stanojlović, R., Andrić, Lj., Štirbanović, Z., Ćirić, N. (2019) The effect of different collectors on the flotation results in the copper mine Majdanpek, In: Proceedings of XIII International Mineral Processing and Recycling Conference, 8-10 May 2019, Belgrade, Serbia, pp. 213-218.

[33] Đorđievski, S., Petrović, J., Krstić, V., Stevanović, Z., Marković, R., Jonović, R., Avramović, L. (2016) Comparative XRD and XRF analysis of selected mine waste samples from Oštreljski Planir dump (Bor, Serbia). Recycling and sustainable development, 9 (1), 21-27.

[34] Marković, Z., Milanović, D., Ljubojev, V. (2012) Mineralogical, chemical and physical characterization of copper ore from the deposit "North Mining District" Copper mine Majdanpek. Rudarski radovi, Bor, (3), 17-32.

[35] Stanojlovic, R., Sokolovic, J., Ciric, N., (2014) Technological requirements of new copper smelter of RTB Bor, a great challenge for the mining profession and science, Mining and Metallurgy Engineering Bor, (4) 49-64. 


\title{
FLOTACIJSKA ISPITIVANJA MAJDANPEČKE RUDE BAKRA U CILJU POBOLJŠANJA ISKORIŠĆENJA BAKRA I KVALITETA KONCENTRATA PRIMENOM RAZLIČITIH KOLEKTORA
}

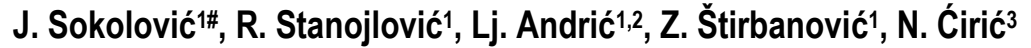 \\ 1 University of Belgrade, Technical Faculty in Bor, V.J. 12, 19210 Bor, Serbia \\ ${ }^{2}$ Institute for Technology of Nuclear and other Mineral Raw Materials (ITNMS), \\ Bulevar Franše d'Eperea 86, 11000 Belgrade, Serbia \\ 3Zijin Bor Copper d.0.o, Copper Mine Majdanpek - RBM, Svetog Save 2, 19250 Majdanpek, Serbia \\ (Primljen: 25. Oktobar 2019.; Prihvaćen: 25. Novembar 2019.)

\begin{abstract}
Izvod
U ovom radu predstavljeni su rezultati mineraloških i flotacijskih ispitivanja rude bakra iz ležišta "Severni revir" u Rudniku bakra Majdanpek, primenom različitih kolektora. XRD i rudna mineraloška analiza pokazali su da su u najčešći prisutni minerali pirit $i$ halkopirit. Hemijske analize potvrđuju da je to compleksna, nisko-kvalitetna ruda bakra sa prosečnim sadržajem bakra od 0,273\%. Sadržaj plemenitih metala (Au i Ag) iznosio je 0,2 g/t, odnosno 1,2 g/t, respektivno. Glavni cilj flotacijskih ispitivanja bio je uticaj vrste kolektora na iskorišćenje i kvalitet koncentrata u procesu flotacije bakra. U testovima osnovnog flotiranja rude bakra korišćeni su različiti kolektori i kombinacije istih. Iskorišćenje bakra iznosilo je opsegu od 79,43\% (test br. 4) do 84,96\% (test br. 7). Najbolji rezultati flotiranja dobijeni su sa sledećm mešavinom kolektora: natrijum izopropil ksantat (Z11), dialkil ditiofosfat (Aerophine 3404) i SKIK BZ 2000. Sa dozom kolektora od 20 g/t Z11, 8 g/t AP3404 i 8 g/t SKIK BZ 2000 ostvareno je iskorišćenje bakra $(84,96 \%)$ sa sadržajem bakra u koncentratu od $1.52 \%$.
\end{abstract}

Ključne reči: Bakar; Ruda; Majdanpek; Flotacija; Kolektori. 